书刊簡介

《电子显微鏡下的病毒》

（二版修訂本）

高劣落著

科学出殿社出版

本书从第一版出版后的两年中, 关于病毒研究 有了进一步的发展，特別是电子显微镜本身放大与 分辩能力的提高，以及制片、染色、金属投影、超 薄切片、快速冻干、负染色等新技术的发明与改 进, 从而使人们对病毒的概念有了进一步的了解与 认识。

本书收集了国內外和作者自己工作中许多有关 病毒方面的电子显微镜照片, 通过这些照片对病毒 的大小、形状、结构以及感染过程等有一个较深刻 的概念。在这一版中，增补了许多新的內容，在某 些地方作了重要的修改，同时还调換和增加了 28 幅照片。本书共分三大部分。

第一部分是噬菌体 (细菌病毒)。文中用 50 多 张炤片, 来说明细菌病的形状、结构及其感染过 程。作者肯定了噬菌体粒子首先是尾部末端吸附在 细菌细胞表面, 便于使签菌体內部物 质 (主 要 是 DNA）进入细菌细胞內部，而外壳（主要是蛋白质） 留在细菌细胞外。噬菌体的蛋白质外壳如一个注射 器, 其尾部如一个注射器的针, 将噬菌体的 DNA 內质注入细菌內。作者特別介绍了这些內部物质主 要是有遗传特征的DNA，除此之外，还有精子多胺、 丁二胺及各种氨基酸和肽类。这些物质与遗传性无 关，传递子代的频率极差。

第二部分是植物病毒。作者通过 50 多张照片 的说明指出, 植物病毒有杆状、球形等, 有时在某 种条件下可以成为结晶体的事实。作者认为, 植物
病毒是由蛋白质及 RNA 组成的，RNA 为中䯣， 外围包有㔻白质的壳, 尽管各种植物病中所含有 核糖核酸的绝对量是一致的, 但它与蛋 白质的比 率, 作者认为是有所差异的。作者还指出, 植物病 毒的感染讨程及其机制的知识至今还是很缺志 的。

第三部分是动物的病瑇。作者列出近 80 张关 于动物病琵的形状、结构、结晶体等方面的电子显 微镜照片, 作者认为, 动物病毒有球、杆、多面体 三种形状, 就其组成上所有的动物病毒中都有 RNA 与 DNA 的特征。

本书作者认为, 病毒不但能引起人类、动物、 植物的疾病, 它也是代表最简单的有机体, 显著地 体现了具有生命物质的主要特征, 如生长、发育、 遗传、变异以及与外界环境的相互反应等, 抹不疑 地它有自己的进化过程, 因此对病毒的研究, 对消 除人类的疾病、減少动植物的受害, 有很大的作 用, 对进一步揭发生命起源的本质, 也有很大的意 义。

\section{[馬月英 $]$}

\section{《茶叶論交选集》}

中国园艺学会編

农业出版社出版

本书是中国园艺学会 1962-1963 年年会上有 关茶叶的 18 篇论文报告，按其內容分为四部分。

第一部分是有关茶树遗传吺化及良种繁殖等方 面的, 解放以来, 我国各茶区对茶树良种的需要十 分迫切，各地对茶树良种北移南迁进行了许多研 究。其中, “茶树南种北移与北种南迁”一文, 对湖 南长沙地区引种云南大叶种与陕西槠叶种的研究, 由实践出发，从理论上概括了茶树引种繁育方面的 问题。

第二部分是有关茶树载培、茶国管理方面的， 其中，“论目前我国旧茶园改造”一文，分析了我国 